\title{
Pernicious anaemia and hypogammaglobulinaemia in a patient with severe infantile kyphoscoliosis
}

\author{
FRANK I. LEE \\ M.B., F.R.C.P.
}

\author{
DEREK R. NORFOLK \\ M.B., M.R.C.P.
}

\section{Department of Medicine (Gastroenterology), Victoria Hospital, Blackpool}

\begin{abstract}
Summary
A 27-year-old man with severe infantile kyphoscoliosis suffered from recurrent respiratory tract infections during childhood and early adult life. He deteriorated and was found to have pernicious anaemia and common variable immunodeficiency with hypogammaglobulinaemia and impairment of cellmediated immunity. Marked clinical improvement has followed the institution of effective $\gamma$-globulin replacement.
\end{abstract}

\section{Case report}

A Caucasian male born in 1947. Occupationoptical technician. In 1974 he was referred to hospital with a story of frequent respiratory infections anorexia, malaise and weight loss. Scoliosis of the thoracic spine, convex to the left, had been noticed when he was a few weeks old. Spina bifida occulta of S1 and S2 was found but there were no abnormal neurological signs and no other structural vertebral abnormalities.

The curve worsened slowly throughout childhood despite the use of a Milwaukee brace, dorsal epiphyseodesis in 1958 and a further spinal fusion procedure in 1961. Since the age of 17 years a thoracic curve of about $90^{\circ}$ has been present. At the age of 6 years he presented with recurrent upper respiratory infections, and an enlarged mass of tonsillar and adenoidal lymphoid tissue was removed. Symptoms persisted, despite bilateral antral lavage and removal of further adenoidal tissue in 1956. From about the tenth year he developed frequent episodes of conjunctivitis and respiratory infection with the production of copious amounts of purulent sputum. There was no family history of skeletal or immunological disease. Clinical examination revealed an emaciated man with a severe thoracic scoliosis (Fig. 1). He was clinically anaemic and coarse crepitations were audible in the chest, maximal in the left lower zone. Weight $31 \mathrm{~kg}$. Intelligence normal.

\section{Investigations}

Chest X-ray confirmed severe kyphoscoliosis with left lower lobe shadowing compatible with bronchiectasis. $\mathrm{Hb}, 7 \cdot 3 \mathrm{~g} / \mathrm{dl}$; MCV, $119 \mathrm{fl}$; WCC, 4300; normal differential count, macrocytosis. Serum vitamin $B_{12}, 25 \mathrm{ng} / 1$; serum folate, $11.5 \mu \mathrm{g} / \mathrm{l}$. Antibodies to gastric parietal cells and intrinsic factor not detected in the serum. Pentagastrin stimulation produced no gastric acid or intrinsic factor secretion. Schilling test-24-hr excretion of radioactive vitamin $B_{12} 2 \%$ increased to $4.6 \%$ with intrinsic factor. Fasting serum gastrin 5 pmol/1 (normal $<50$ ). Normal thyopac test and urine examination for mucopolysaccharides. Faecal fat $4 \mathrm{mmol} / 24 \mathrm{hr}$. Plasma protein electrophoresis revealed marked hypogammaglobulinaemia and immunodiffusion showed undetectable levels of serum IgG and IgA and $1.4 \mathrm{~g} / 1$ of IgM. HLA tissue type A3.B7.BW22.

Gastric biopsies (suction) showed atrophic gastritis with involvement of the antrum where intestinal metaplasia was present. Small intestinal biopsy (Crosby capsule) normal. Immunological studies are shown in Table 1.

\section{Progress}

Treatment with hydroxycobalamin injections produced improvement in the clinical and haematological state. He remained well for some months but early in 1976 his general health deteriorated with severe, watery diarrhoea, weight loss and frequent respiratory tract infections. There was no steatorrhoea and the diarrhoea was controlled with codeine phosphate. Transient improvement appeared to follow courses of tetracycline and metronidazole. Examination of stools for pathogenic bacteria and of stools and biopsy specimens for Giardia lamblia organisms and cysts was negative. His condition remained poor throughout 1976 although, following the finding of iron deficiency, he improved for a while with oral iron therapy. He again deteriorated with more weight loss and respiratory infections in spite of attention to general measures and appropriate antibiotics. In February 1977 regular $\gamma$ globulin injections were begun following loading infusion of 6 units of fresh frozen plasma. The latter route was used on account of poor musculature. 


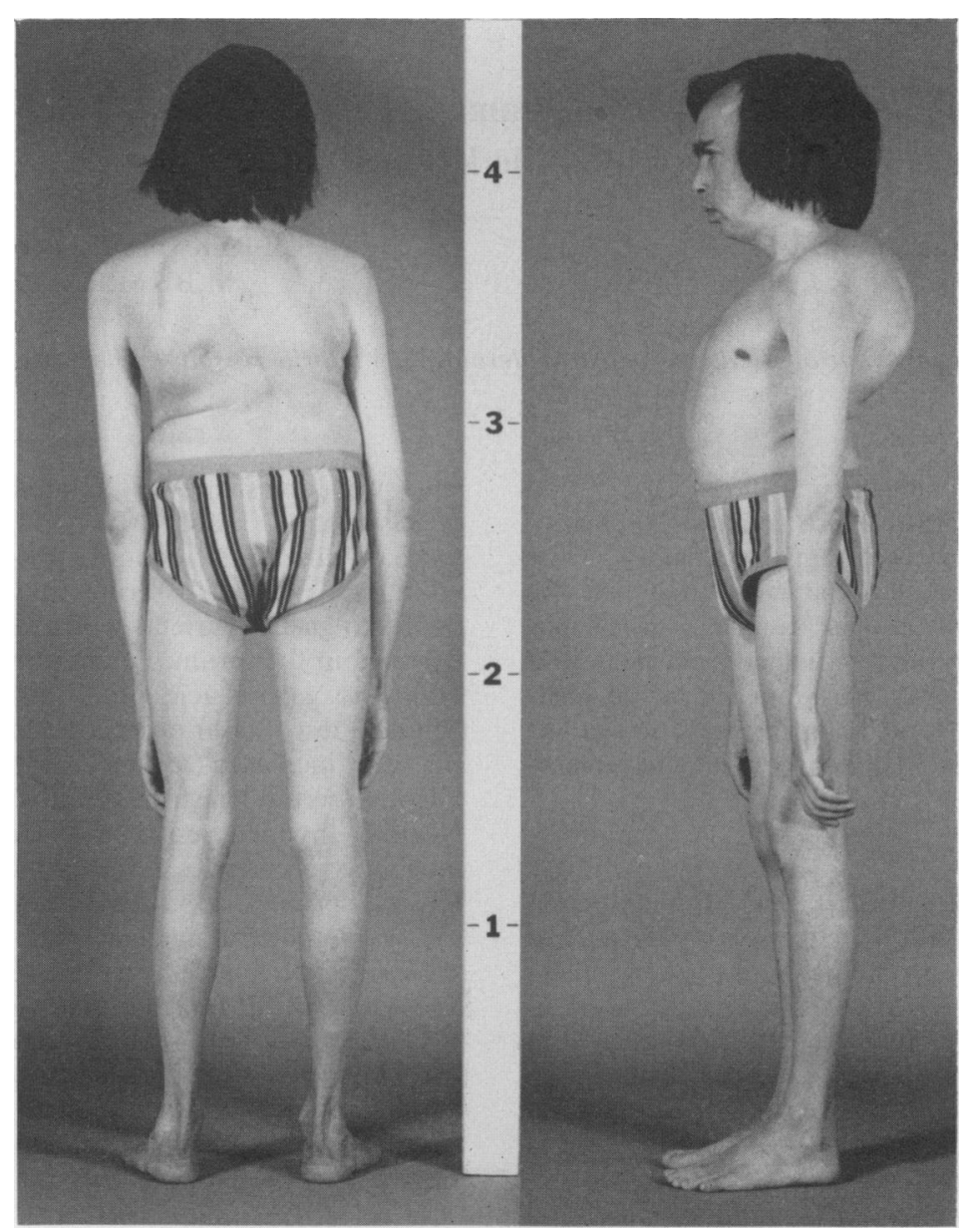

FIG. 1. The patient.

TABLE 1. Immunological studies

Immunoglobulin levels-(Dec. 1974) $\quad$ IgG-0. IgA-0. IgM-1.4 g/1.

Parietal cell antibodies

Intrinsic factor antibodies

$T$ cells and $B$ cells

Migration inhibition

Lymphocyte transformation test

Skin sensitivity test

\section{\} Negative.}

Normal numbers.

No significant inhibition of leucocyte migration to extracts of gastric mucosa (human)-normal.

Impaired lymphocyte transformation response-phytohaemagglutinin $-2 \cdot 0 \mu \mathrm{g} / \mathrm{ml}-$ $0 \cdot 2 \mu \mathrm{g} / \mathrm{ml}$ pokeweed mitogen, PPD Candida albicans

Normal response-tetanus toxoid.

Candida albicans $-0.02 \mathrm{ml}-33 \%$-no reaction

PPD

$$
-0.1 \mathrm{ml}-33 \% \text {-no reaction }
$$

Sensitized to dinitrochlorobenzene (DNCB) with $2000 \mu \mathrm{g}$ as patch test. No reaction to $10,30,50 \mu \mathrm{g}$ challenges. 
Weekly $\gamma$-globulin, $6.7 \mathrm{ml}$, was given but clinical improvement was slow and this was reflected in ineffective therapeutic levels of IgG (Fig. 2). He has been on a maintenance double dose since September 1977 with corresponding increase in levels (Fig. 2). Concurrently there has been a marked improvement in his clinical state reflected in weight gain and return of bowel habit to normal. Respiratory tract infections have been much less troublesome, usually associated with Haemophilus influenzae infection responding to amoxycillin. He has returned to his job as an optical technician.

\section{Discussion}

Pernicious anaemia, when associated with hypogammaglobulinaemia, occurs at a younger age than the classical variety (Twomey, 1978) and the occurrence of pernicious anaemia and other autoimmune diseases in family members has been noted (Lee et al., 1964; Gelfand et al., 1972). In such patients, the associated gastric atrophy involves the antrum in addition to the body, as in classical uncomplicated pernicious anaemia and this is accompanied by normal or low levels of serum gastrin (Hughes, Brooks and Conn, 1972). The gastritis is associated with an increased incidence of complicating carcinoma of the stomach (Twomey, 1978).

Recognized respiratory complications include sinusitis, bronchitis, pneumonia and bronchiectasis (Douglas, Goldberg and Fudenberg, 1970). The presence of enlarged tonsillar lymphoid tissue is inconsistent with a diagnosis of congenital hypogammaglobulinaemia (Charache et al. 1965) in this patient who demonstrates many of the characteristic features of common variable immunodeficiency (CVI). Severe combined immunodeficiency of childhood may be associated with short-limbed dwarfism, and various skeletal abnormalities have been described in children with certain enzyme deficiency syndromes and immunodeficiency (Ammann, 1977). However, apart from increased susceptibility to septic arthritis and reports of a 'rheumatoid-like' arthritis which responds to $\gamma$-globulin injections (Webster et al., 1976), CVI has rarely been associated with skeletal disease.

Idiopathic infantile scoliosis is defined as 'a structural curve without discoverable cause before the age of 3 years' (James, 1967). There is a male preponderance and the curve is more often convex to the left unlike the more common adolescent scoliosis. As many as $90 \%$ of these curves may resolve spontaneously (Lloyd Roberts and Pilcher, 1965) but the progressive variety is often associated with the development of cardio-respiratory disease. Ventilation/perfusion imbalance and recurrent respiratory infection lead to pulmonary hypertension and eventually cor pulmonale (Bergofsky, Turino and Fishman, 1959). The aetiology of the scoliosis is speculative (Leading Article, 1976), but it has been associated with a variety of conditions including congenital heart disease, congenital dislocation of the hip and mental retardation.

In this man the increased susceptibility to infection

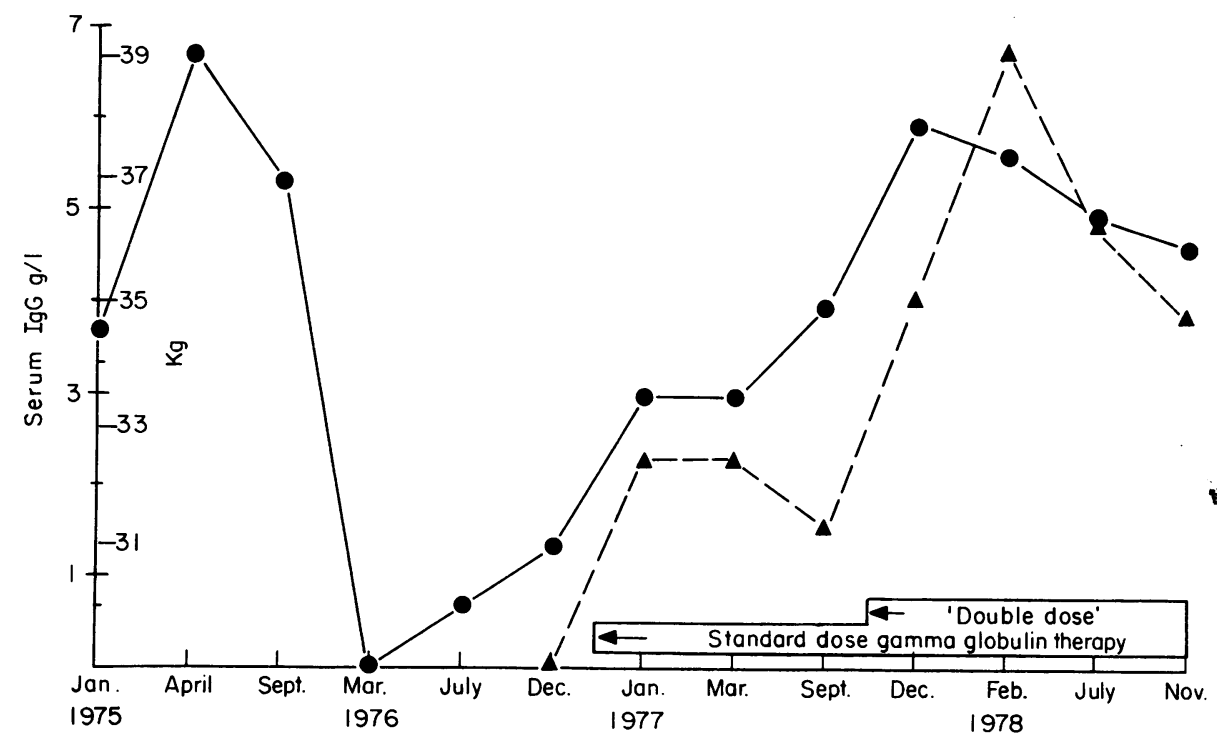

FIG. 2. Serial observations on weight (-) and serum IgG levels $(\mathbf{A}-\mathbf{-}-\mathbf{A})$ before and during replacement $\boldsymbol{\gamma}$-globulin injections. 
consequent on immunodeficiency and the pulmonary problems of a gross scoliosis clearly combine in producing chronic respiratory disease. Variable defects in cell-mediated and humoral immunity are common in CVI but much recent work on T and B lymphocyte function has failed to elucidate its aetiology, merely demonstrating its considerable clinical and immunological heterogeneity (Geha et al., 1974; Siegal, Siegal and Good, 1978). Diarrhoea is a common problem and may be associated with malabsorption (Allen and Hadden, 1964). Giardiasis (Douglas et al., 1970), lymphoid nodular hyperplasia (Webster et al., 1973) or deconjugation of bile salts by bacterial contamination of the small intestine (Gleich and Hofmann, 1971) may be detected. An interesting observation in the present patient is the fact that his diarrhoea has improved markedly since the institution of regular $\gamma$-globulin injections which were, in fact, started with a view to reducing chest infection.

\section{Acknowledgments}

We are grateful to Dr I. Delamore for intrinsic factor assay, to Dr D. Lee for tissue antigen typing and, in particular, to Dr M. Haeney at the Regional Immunology Laboratory, East Birmingham Hospital, for much helpful advice and investigation, and to Dr Rees Jones of the same Institute for $\boldsymbol{\gamma}$-globulin supplies.

\section{References}

Allen, G.E. \& Hadden, D.R. (1964) Congenital hypogammaglobulinaemia with steatorrhoea in two adult brothers. British Medical Journal, 2, 486.

AmmanN, A.J. (1977) Immunodeficiency with short-limbed dwarfs. Pediatric Clinics of North America, 24, 305.

Bergofsky, E.H., Turino, G.M. \& Fishman, A.P. (1959) Cardiorespiratory failure in kyphoscoliosis. Medicine. Baltimore, 38, 263.

Charache, P., Rosen, F.S., Janeway, C.A., Craig, J.M. \&
Rosenberg, H.A. (1965) Acquired agammaglobulinaemia in siblings. Lancet, i, 234.

Douglas, D.D., Goldberg, L.S. \& Fudenberg, H.H (1970) Clinical, serologic and leucocyte function studies onc. patients with idiopathic "acquired" agammaglobulinemia and their families. American Journal of Medicine, 48, 48. जे

Geha, R.S., Schneeberger, E., Merler, E. \& Rosen, F.S(1974) Heterogeneity of "acquired" or common variablec agammaglobulinemia. New England Journal of Medicine 291, 1.

GelfaNd, E.W. Berkel, A.L., Godwin, H.A., Rocklin P.E., DAvid, J.R. \& Rosen, F.S. (1972) Pernicious anaemia, hypogammaglobulinaemia and altered lymphocytes reactivity. Clinical and Experimental Immunology, 11, 187. GLEICH, G.J. \& HofMANN, A.F. (1971) Use of cholestyramine to control diarrhea associated with acquired hypogamma globulinemia. American Journal of Medicine, 51, 281.

Hughes, W.S., Brooks, F.P. \& ConN, H.O. (1972) Serum gastrin levels in primary hypogammaglobulinemia an\&o근 pernicious anemia. Annals of Internal Medicine, 77, 746.

JAMES, J.I.P. (1967) Scoliosis, p. 55. E. \& S. Livingstone Ltdị Edinburgh and London.

LEADING ARTICLE (1976) Mechanisms in scoliosis. Lancet, ii 1234.

LeE, F.I., Jenkins, G.C., Hughes, D.T.D. \& Kazantzis, Gĩ (1964) Pernicious anaemia, myxoedema and hypogamma globulinaemia. British Medical Journal, 1, 1598.

Lloyd Roberts, G.C. \& PIlcher, M.F. (1965) StructuraP idiopathic scoliosis in infancy. Journal of Bone and Joint $\vec{L}$ Surgery, 47-B, 520

Siegal, F.P., Siegal, M. \& Good, R.A. (1978) Role of helper, suppressor and $\beta$-cell defects in the pathogenesis of the hypogammaglobulinemias. New England Journal of Medicine, 299, 172.

TwOMEY, J.J. (1978) Immunological dysfunction atrophic gastritis and gastric malignancy. In: Gas $\dot{0} 0$ intestinal Tract Cancer. (Ed. by Lipkin, M. \& Good, R. p. 93. Plenum Medical, New York and London.

Webster, A.B.D., Asherson, G.L., Ballard, J., Shiner, M.ळ Slavin, G., Levi, J. \& Kenwright, S. (1973) Immung్ deficiency disease and lymphoid nodular hyperplasia. Gut $\mathrm{D}$ 14, 829.

Webster, A.B.D., LOEWI, G., DOURMashKin, R.D. $\overrightarrow{\overline{0}}$ Goulding, D.N., Ward, D.J. \& Asherson, G.L. (1976B Polyarthritis in adults with hypogammaglobulinaemia and its rapid response to immunoglobulin therapy. Britis Medical Journal, 1, 1314. 